\title{
SISTEM REKAYASA INTERNET PADA IMPLEMENTASI RUMAH RUMAH PINTAR BERBASIS IoT
}

\author{
Andi Hildayanti', M. Sya'rani Machrizzandi² \\ ${ }^{1}$ Jurusan Teknik Arsitektur, Universitas Islam Negeri Alauddin Makassar, Indonesia \\ ${ }^{2}$ Jurusan Teknik Informatika, Universitas Islam Negeri Alauddin Makassar, Indonesia \\ 1.andi.hildayanti@uin-alauddin.ac.id, ²sya'rani.machrizzandi@uin-alauddin.ac.id
}

\begin{abstract}
ABSTRAK
Seiring perkembangan teknologi yang semakin meningkat dan pesat, segala sesuatu dibuat lebih mudah dengan bantuan rekayasa teknologi. Salah satunya telah dikembangkan dalam skala unit rumah yang mulai dikenal dengan istilah rumah pintar. Rumah ini didukung oleh rekayasa teknologi berbasis internet yang memudahkan penghuni menjalankan aktivitas didalam maupun diluar rumah. Kemudahan yang ditawarkan menjadi daya tarik sendiri bagi banyak kalangan masyarakat. Teknologi ini sedikitnya sudah menjawab beberapa impian rumah masa depan bagi sebagian masyarakat, tidak terkecuali di Indonesia. Oleh karena itu, penelitian ini bertujuan untuk menganalisis penggunaan system rekayasa teknologi internet dalam mewujudkan rumah pintar (smart home). Dengan menggunakan metode deskriptif, penelitian ini mampu menunjukkan bahwa rumah pintar dengan teknologi Internet of Things (IoT) menyediakan kenyamanan, keamanan, efisiensi energi bagi rumah setiap saat karena dapat dikontrol dari jarak jauh sehingga memudahkan penghuni untuk mengontrol keamanan rumah meski tanpa bantuan petugas keamanan. Salah satu rekayasa teknologi dapat mewujudkan rumah pintar tersebut adalah teknologi internet of things (IoT). Internet yang dapat digunakan di semua perangkat membuat penggunanya bisa berinteraksi langsung dengan beberapa perangkat rumah tangga yang ada dirumah.
\end{abstract}

Kata Kunci- hunian, rumah pintar, system rekayasa internet, internet of things, efisiensi energi, keamanan dan kenyamanan.

\begin{abstract}
As the increasing development of technology, everything is made easier with technological engineering helped. One of them has been developed on a home scale which is becoming known as a smart home. This home is supported by internet-based technology engineering that makes it easy for residents to carry out activities inside and outside the home. The convenience offered is the main attraction for many people. This technology has answered at least some dreams of a future home for some people, including in Indonesia. Therefore, this study aims to analyze the use of internet technology engineering systems in realizing a smart home. By using a descriptive method, this study is able to show that a smart home with Internet of Things (IoT) technology provides comfort, security, energy efficiency for the home at any time because it can be controlled remotely, making it easier for residents to control home security even without the help of security officers. One of the technological engineering that can make this smart home is the internet of things (IoT) technology. Internet that can be used on all devices allows users to interact directly with several household devices at home.
\end{abstract}

Keywords - housing, smart homes, internet engineering systems, internet of things, energy efficiency, security and comfort 


\section{PENDAHULUAN}

Rumah adalah tempat tinggal (hunian) yang menjadi kebutuhan primer masyarakat selain kebutuhan pangan. Rumah dapat diartikan sebagai sebuah tempat di mana penghuninya akan mendapatkan perlindungan atau tempat bernaung dari segala kondisi alam yang berada di sekitarnya, seperti hujan, panas terik matahari, dan sebagainya [1]. Rumah juga merupakan sesuatu yang dijadikan tempat beristirahat penghuninya yang telah melakukan berbagai macam aktivitas di luar.

Terlepas dari pengertiannya, rumah memiliki beberapa fungsi khususnya bagi penghuninya. Menurut Turner (1976) rumah memiliki beberapa fungsi utama [2][3], di antaranya adalah sebagai berikut:

a. Sebagai penunjang rasa aman (security), yaitu rumah merupakan jaminan bagi penghuninya sebagai tempat yang akan memberikan rasa aman berupa rasa kepemilikan bangunan rumah dan lahan (the form of tenure).

b. Sebagai penunjang kesempatan (opportunity), yaitu rumah juga merupakan suatu sarana yang dapat dijadikan sebagai penunjang kesempatan bagi yang menempatinya di mana untuk dapat mengembangkan kehidupan sosial budaya dan ekonomi atau fungsi pengemban keluarga.

c. Sebagai penunjang identitas keluarga (identity), yaitu rumah sebagai tempat tinggal juga dimaksudkan supaya penghuni dapat memperlihatkan identitas serta statusnya berdasarkan rumah yang dimilikinya.

Dalam teori human ecology disebutkan hunian sebagai suatu hasil karya arsitektur manusia penghuninya merupakan sebuah system lingkungan hidup yang mempunyai ketergantungan dan kesetimbangan antara eco system (sistem lingkungan hidup) dan social system (system lingkungan sosial). Eco system terdiri dari unsur boitik dan abiotik yang memuat kondisi fisik dan fisiologis lingkungan dalam suatu standar untuk mencapai kenyamanan dan kepuasan fisik maupun fisiologis; sedangkan social system memuat unsur jiwa manusia sebagai pribadi dan sosial yang memiliki kehendak untuk memenuhi kebutuhan psikologis dalam berkegiatan dan berperilaku dengan lingkungannya.

Sebagai pemenuhan dan pencerminan identitas karakteristik penghuni sesuai dengan perkembangan sosial yang terjadi [4], maka kecenderungan konsep membangun arsitektur hunian akan direpresentasikan terhadap tata cara membangun secara fisik (menyangkut sistem teknologi, pemakaian, material kesesuaian iklim) serta proses bermukim secara non fisik (keterkaitan dengan kondisi budaya, religi dan perilaku masyarakat), sebagaimana dikemukakan oleh Rapoport (1969) [5]. Dengan demikian, sebagai suatu corak/gaya sebuah periode/masa, arsitektur akan berkembang sejalan dengan konteks perkembangan budaya. Namun, perkembangan hanya terjadi ketika timbul motivasi keagamaan dan kreativitas seni serta teknologi ketrampilan yang cukup baik sebagai sumber ekonomi yang memberikan harmonisasi kemanusiaan.
Seiring perkembangan teknologi yang semakin meningkat dan pesat, segala sesuatu dibuat lebih mudah dengan bantuan rekayasa teknologi. Hal ini juga terjadi pada perkembangan rumah pintar yang didukung oleh rekayasa teknologi yang memudahkan penghuni dalam menjalankan aktivitas didalam maupun diluar rumah. Bahkan telah ada rumah yang dapat dikontrol dari jarak jauh sehingga memudahkan penghuni untuk mengontrol keamanan rumah meski tanpa bantuan petugas keamanan. Salah satu rekayasa teknologi dapat mewujudkan rumah pintar tersebut adalah teknologi internet of things (IoT). Teknologi ini sedang marak dikembangkan oleh banyak perusahaan yang bekerja sama dengan perusahaan furniture, developer bangunan, dan lainnya. Kemudahan yang ditawarkan menjadi daya tarik sendiri bagi banyak kalangan masyarakat. Teknologi ini sedikitnya sudah menjawab beberapa impian rumah masa depan bagi Sebagian masyarakat, tidak terkecuali di Indonesia. Oleh karena itu, penelitian ini bertujuan untuk menganalisis penggunaan system rekayasa teknologi internet dalam mewujudkan rumah pintar (smart home).

\section{TINJAUAN PUSTAKA}

\subsection{Rumah Pintar}

Rumah Pintar / Smart Home adalah sebuah rumah yang dilengkapi dengan perangkat dan perabot canggih sehingga semua fungsi rumah tangga dapat dikendalikan dengan remote kontrol (nirkabel). Ciri khas mendasar dari rumah pintar ini yaitu, pagar, pintu, dan jendela rumah dapat dibuka tutup hanya dengan menekan remote kontrol.

Bukan hanya itu, dengan remote kontrol pemilik rumah dapat menyalakan dan mematikan $\mathrm{TV}$, radio, komputer, rice cooker, dispenser, kulkas, AC, dan perangkat elektronik lainnya. Bahkan, di era maju seperti saat ini, melalui teknologi komputer, internet, aplikasi-aplikasi pemrograman (software), dan dukungan sistem operasi seperti android, sistem pengendali perangkat dan perabot rumah pintar telah dapat berbasis ponsel pintar.

Dengan demikian, rumah pun dapat dikontrol, diawasi dan dikendalikan dari jarak jauh oleh pemilik rumah. Untuk level paling tinggi, pemilik rumah pun dapat melengkapi rumah pintarnya dengan sistem keamanan berupa alarm, kamera pengintai, jebakan rahasia, dan pemanggil call center polisi otomatis.

Sedangkan untuk kenyamanan, pemilik rumah dapat melengkapi rumah dengan robot pintar untuk urusan rumah tangga seperti memasak, membersihkan, mencuci, melipat pakaian, menyetrika, dan sebagainya. Intinya, semakin banyak dan canggih teknologi yang digunakan di dalam sebuah rumah, maka semakin tinggi level kepintarannya.

Ada banyak manfaat yang dapat diperoleh oleh penghuni rumah yang menerapkan konsep rumah pintar dengan teknologi Internet of Things ini, diantaranya adalah:

a. Konsep smarthome akan meningkatkan keamanan rumah [6]. Terutama ketika pemilik rumah sedang 
berpergian jauh dan dalam jangka waktu yang cukup lama, sehingga mereka tak perlu merasa khawatir, karena dapat dipantau atau memonitor rumah dari jarak jauh kapan dan di mana saja melalui penggunaan kamera CCTV yang terintegrasi dengan sistem pengendali jarak jauh melalui smartphone.

b. Smarthome memudahkan aktivitas harian. Contohnya ketika pemilik rumah memiliki kontrol terhadap pencahayaan rumah. Pencahayaan rumah pintar dirancang dengan mempertimbangkan efisiensi energi. Baik di tempat kerja maupun di rumah, pencahayaan cerdas dapat secara otomatis menyesuaikan dengan kondisi hunian di siang hari. Hal ini dapat membantu mengurangi biaya listrik rumah tersebut dan dapat membatu mereduksi pemanasan global.

c. Teknologi rumah pintar juga melindungi pemilik rumah dari tamu tak diundang. Dengan mengadopsi rumah pintar yang menggunakan fitur tambahan kunci pintar, seperti pemindai kartu, sidik jari, hingga penggunaan kode sandi, selain dikunci secara manual, maka tidak sembarang orang bisa masuk ke rumah tersebut. Di samping itu, seperti di hotel/apartement, di rumah pun sudah bisa melihat wajah tamu yang datang melalui kamera yang terintegrasi dengan smartphone.

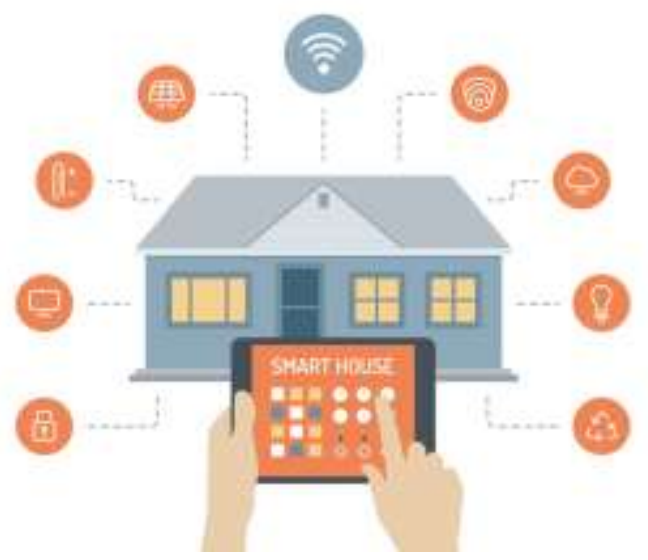

Gambar 1. Smart home yang mengedepankan konsep rumah berbasis aplikasi teknologi.[7]

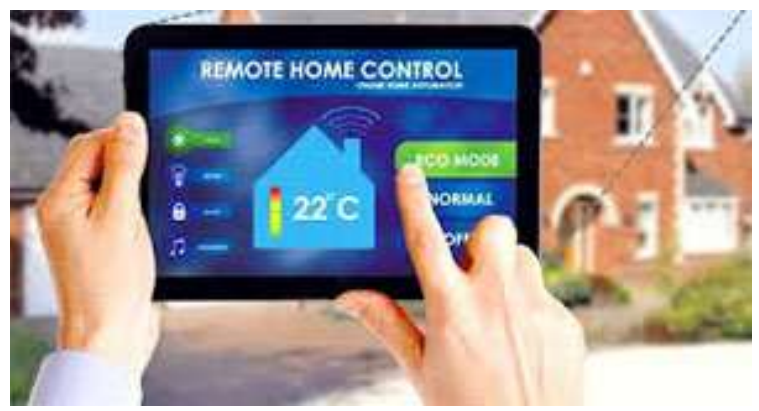

Gambar 2. Konsep smart home memudahkan penghuni mengontrol semua kegiatan dalam satu perangkat. [7]

\subsection{Internet of Things}

Internet of Things atau IoT pertama kali dikeluarkan oleh Kevin Ashton pada tahun 1999 di salah satu presentasinya. Kini banyak perusahaan besar mulai mendalami Internet of Things sebut saja Intel, Microsoft, Oracle, dan banyak lagi lainnya.

Banyak yang memprediksikan bahwa IoT adalah "The Next Big Thing" di dunia teknologi informasi, hal ini karena IoT menawarkan banyak potensi yang bisa dikembangkan kembali. Contohnya adalah implementasi dari internet of Things (IoT) misalnya adalah kulkas yang dapat memberitahukan kepada pemiliknya via SMS atau email tentang makanan dan minuman apa saja yang sudah habis dan harus distok lagi.

Bagi pengembang, kini banyak perusahaan yang menyediakan berbagai macam program untuk membantu pengembang dalam mengembangkan produk berbasis Internet of Things. Salah satu yang menyediakan program ini adalah Intel dengan IoT Developer Program mereka.

Pada dasarnya Internet of Things adalah suatu konsep dimana objek tertentu punya kemampuan untuk mentransfer data lewat jaringan tanpa memerlukan adanya interaksi dari manusia ke manusia ataupun dari manusia ke perangkat computer [6].

Internet of Things leih sering disebut dengan singkatannya yaitu IoT. IoT ini sudah berkembang pesat mulai dari konvergensi teknologi nirkabel, microelectromechanical systems (MEMS), dan juga Internet. IoT ini juga kerap diidentifikasikan dengan RFID sebagai metode komunikasi. Namun, IoT juga bisa mencakup teknologi-teknologi sensor lainnya, semacam teknologi nirkabel maupun kode QR.

Adapun kemampuannya bermacam-macam contohnya dalam berbagi data, menjadi remote control, dan masih banyak lagi yang lainnya. Sebenarnya fungsinya termasuk juga diterapkan ke benda yang ada di dunia nyata. Contohnya adalah untuk pengolahan bahan pangan, elektronik, dan berbagai mesin atau teknologi lainnya yang semuanya tersambung ke jaringan lokal maupun global lewat sensor yang tertanam dan selalu menyala aktif.

Jadi, sederhananya istilah Internet of Things ini mengacu pada mesin atau alat yang bisa diidentifikasikan sebagai representasi virtual dalam strukturnya yang berbasis Internet. Sebenarnya IoT bekerja dengan memanfaatkan suatu argumentasi pemrograman, dimana tiap-tiap perintah argumen tersebut bisa menghasilkan suatu interaksi antar mesin yang telah terhubung secara otomatis tanpa campur tangan manusia dan tanpa terbatas jarak berapapun jauhnya. Jadi, Internet di sini menjadi penghubung antara kedua interaksi mesin tersebut. Manusia dalam IoT tugasnya hanyalah menjadi pengatur dan 
pengawas dari mesin-mesin yang bekerja secara langsung tersebut.

Adapun beberapa contoh manfaat dari Internet of Things (IoT) dari berbagai bidang, antara lain adalah:

\section{a. Bidang Pertanian}

Ada berbagai macam pengaplikasian IoT di sektor pertanian. Beberapa diantaranya seperti mengumpulkan data soal suhu, curah hujan, kelembaban, kecepatan angin, serangan hama, dan muatan tanah. Data-data tersebut bisa dipakai buat mengotomatisasi teknik pertanian. Kemudian, dapat juga dipakai untuk mengambil keputusan (decision making) berdasarkan informasi yang ada demi meningkatkan kualitas dan kuantitas, meminimalkan risiko dan limbah, serta mengurangi upaya yang diperlukan dalam mengelola tanaman. Sebagai contoh, petani sekarang sudah bisa memantau suhu dan kelembaban tanah dari jauh, dan bahkan menerapkan data yang diperoleh IoT untuk program pemupukan yang lebih presisi.

\section{b. Bidang Energi}

Sejumlah besar perangkat yang memakan energi (semacam switch, outlet listrik, lampu, televisi, dan lainnya) kini sudah bisa terintegrasi dengan konektivitas internet. Integrasi tersebut memungkinkan mesin-mesin ataupun jaringan untuk berkomunikasi dalam menyeimbangkan pembangkitan listrik serta penggunaan energi yang lebih hemat maupun efektif. Perangkat ini juga bisa memungkinkan akses remote control dari pengguna, atau bisa juga manajemen dari satu pusat lewat interface yang berberbasis cloud. Selain itu, bisa juga mengaktifkan fungsi semacam penjadwalan (misalnya untuk menyalakan/mematikan mesin pemanas, mengendalikan oven, mengubah kondisi pencahayaan dari terang menjadi redup hingga ke gelap, dan lain sebagainya). Jadi dengan IoT di bidang ini, sistem bisa berkumpul dan bertindak berdasarkan informasi yang terkait dengan energi dan daya demi meningkatkan efisiensi produksi dan distribusi listrik.

\section{c. Bidang Lingkungan}

Aplikasi pemantauan lingkungan dari IOT biasanya pakai sensor dalam membantu terwujudnya perlindungan lingkungan. Penerapannya misalnya dengan memantau kualitas udara atau air, kondisi atmosfer atau tanah, bahkan juga bisa mencakup pemantauan terhadap satwa liar dan habitatnya. IoT juga dimanfaatkan dalam penanggulangan bencana semacam sistem peringatan dini Tsunami atau gempa bumi. Hal ini tentunya bisa sangat membantu. Perangkat IoT dalam hal ini berarti punya jangkauan geografis yang sangat luas serta mampu bergerak.

\section{d. Bidang Otomatisasi Rumah}

Perangkat IoT juga bisa dipakai untuk memantau dan mengontrol sistem mekanis, elektrik, dan elektronik yang digunakan di berbagai jenis bangunan (misalnya, industri atau juga rumah Anda sebagai tempat tinggal). Alat atau pengembangan IoT ini juga bisa memantau penggunaan energi secara real-time untuk mengurangi konsumsi energi. Selain itu, bahkan dapat juga melakukan pemantauan terhadap para penghuninya. Begitu masuk ke rumah di malam hari, lampu menyala. Kemudian begitu masuk ke jadwal tidur, lampu akan mati secara otomatis. Pagi hari, taman akan disiram air oleh mesin penyiram otomatis. Begitu juga dengan kulkas yang bisa memesan stok makanan sendiri ketika habis. Semuanya bisa terintegrasi menjadi sistem rumah pintar.

\section{e. Bidang Medik dan Kesehatan}

Dalam dunia medik dan kesehatan, IoT akan dikembangkan terus. Bahkan, nanti di masa yang akan datang, seluruh rekaman kesehatan bisa ditransfer langsung ke tenaga medis maupun Rumah Sakit. Data-data yang bisa dideteksi dan dikirimkan semacam detak jantung, tingkat gula dalam darah, dan lain sebagainya. Smartphone/ponsel pribadi akan jadi alat pemantau kesehatan yang canggih dan tentunya bisa sangat membantu masyarakat. Perangkat IoT yang ada bahkan bisa memberikan peringatan saat kondisi kesehatan menurun atau memberikan saran pengobatan dan bahkan membuat janji temu dengan dokter. Sebenarnya beberapa teknologi canggih IoT telah dikembangkan dan diterapkan di bidang ini. Contohnya, tempat tidur pintar yang bisa otomatis memberitahukan dokter/perawat ketika pasien hendak bangun dari tempat tidur. Menurut laporan dari Goldman Sachs di tahun 2015, perangkat kesehatan semacam ini bisa menyelamatkan negara dari anggaran kesehatan yang berlebihan.

\section{f. Bidang Transportasi}

IoT bisa membantu manusia dalam integrasi komunikasi, kontrol, dan pemrosesan informasi pada berbagai sistem transportasi yang ada. Penerapan IoT memang terus-menerus meluas ke berbagai aspek sistem transportasi. Tak hanya teknologi mesinnya yaitu kendaraan, tetapi juga infrastruktur, serta menyinggung fungsi pengemudi/penggunanya. Interaksi dinamis yang terjadi antara komponenkomponen itu berasal dari sebuah sistem transportasi. Sistem tersebut memungkinkan komunikasi antar dan intra kendaraan, kontrol lalu lintas yang lebih efektif karena tergolong cerdas, parkir yang lebih cerdas, manajemen logistik dan armada, kontrol kendaraan, dan juga terkait faktor keselamatan maupun bantuan di jalan. 
Jurnal Ilmiah Ilmu Komputer Vol. 6, No. 1, April 2020

Fakultas Ilmu Komputer

Universitas AL Asyariah Mandar

\section{METODE PENELITIAN}

Penelitian ini merupakan penelitian fenomenologi yang bertujuan untuk memahami perubahan dan peningkatan kebutuhan masyarakat terkait teknologi rumah pintar di seiring berkembangnya teknologi di dunia, salah satunya adalah system rekayasa internet berupa Internet of Things. Data yang diolah pada penelitian ini adalah data literatur dan sinkronisasi studi kasus rumah pintar yang telah menerapkan teknologi Internet of Things tersebut. Secara garis besar, data yang digunakan adalah teori yang menyangkut rumah pintar dan Internet of Things yang diperoleh dari berbagai sumber data seperti jurnal, artikel internet, dan sumber lainnya yang relevan dengan teori yang digunakan. Data-data tersebut kemudian dianalisis secara deskriptif guna menghasilkan gambaran penggunaan internet of things dala mewujudkan rumah pintar. Hasil penelitian ini bersifat general sehingga dapat digunakan sebagai referensi bagi penelitian studi kasus.

\section{HASIL PENELITIAN}

Dalam mewujudkan rumah pintar, peran teknologi internet sangat membantu dalam mewujudkan hunian masa depan yang dapat dikontrol dimanapun dan kapanpun meski dengan jarak jauh. Penggunaan perangkat yang terhubung ke internet dalam konsep teknologi rumah pintar memungkinkan penghuni rumah untuk melakukan pemantauan jarak jauh, sekaligus pengelolaan peralatan dan sistem yang digunakan di rumah. Seperti halnya penerangan, pemanasan, kamera, dan lainnya. Kecanggihan teknologi rumah pintar yang umumnya diterapkan di Indonesia maupun dibeberapa negara maju seperti Australia, yakni sebagai berikut:

a. Smart TV yang terhubung ke internet untuk mengakses konten melalui aplikasi, seperti video dan musik berdasarkan permintaan.

b. Sistem pencahayaan pintar yang dapat dikendalikan dengan jarak jauh dan dapat mendeteksi kapan penghuni berada di dalam ruangan, serta menyesuaikan pencahayaan sesuai kebutuhan. Bola lampu pintar juga dapat mengatur diri mereka sendiri berdasarkan ketersediaan siang hari.

c. Smart thermostats, seperti Nest dari Nest Labs Inc., dilengkapi dengan Wi-Fi terintegrasi. Perangkat itu memungkinkan pengguna menjadwalkan, memantau, dan mengontrol suhu rumah dari jarak jauh. Perangkat ini juga mempelajari perilaku pemilik rumah dan secara otomatis mengubah pengaturan untuk memberikan penghuni kenyamanan dan efisiensi maksimum.

d. Kunci pintar dan pembuka pintu garasi otomatis. Dimana pengguna dapat memberikan atau menolak akses kepada tamu. Kunci pintar juga dapat mendeteksi ketika penghuni dekat dan membuka kunci pintu untuk mereka.

e. Dengan kamera keamanan pintar, penghuni dapat memantau rumah mereka saat pergi atau berlibur. Sensor gerak pintar juga dapat mengidentifikasi perbedaan antara penghuni, pengunjung, hewan peliharaan, dan pencuri, serta dapat memberi tahu pihak berwenang jika perilaku mencurigakan terdeteksi.

f. Perawatan hewan peliharaan dapat diotomatisasi dengan pengumpan yang terhubung. Tanaman hias dan halaman rumput dapat disiram melalui penghitung waktu yang terintegrasi.

g. Teknologi peralatan dapur, termasuk pembuat kopi canggih yang dapat membuatkan Anda secangkir segar kopi segera setelah alarm berbunyi; lemari es pintar yang melacak tanggal kadaluarsa, kompor dan pemanggang, mesin cuci, pengering, dan lainnya.

h. Pemantau sistem rumah tangga, misalnya peralatan yang dapat merasakan sengatan listrik, membekukan pipa, dan mematikan air sehingga tidak terjadi banjir di ruang bawah tanah.

Kecanggihan tersebut tidak lepas dari peran unsur dari system rekayasa internet tersebut. Adapun unsur-unsur yang diperlukan dalam membentuk Internet Of Things (IOT) antara lain adalah;

a. Sensor - Sensor meripakan perangkat yang sangat canggih dimana alat ini bisa menangkat atau mendapatkan informasi terkait dari hal hal tertentu seperti sensor gerak, suhu, udara, panas, dan lainnya.

b. Konektivitas - Konektivitas disini berfungsi sebagai penghubung dan pertukaran informasi yang terjadi pada Internet of Things (IOT). Konektivitas ini biasanya yang dibutuhkan harus stabil namun tidak perlu dalam bentuk yang besar juga.

c. Perangkat yang Berukuran Kecil - Perangkat kecil ini dapat mendukung dan meningkatkan ketepatan, skalabilitas dan fleksibel dalam pengembangan IoT. Dan teknologi memang seperti itum makin kecil makin murah dan lebih kuat.

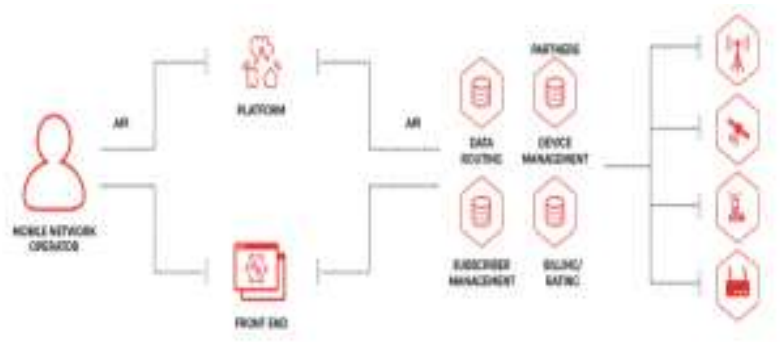

Gambar 3. Hubungan Cloud Computing dan Internet of Things IoT [8] 


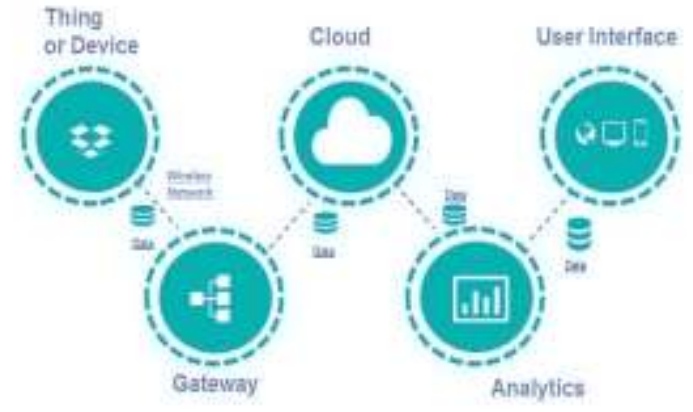

Gambar 4. Alur kerja rekayasa teknologi internet (Internet of Things)

Dengan menggunakan Internet of things segala kemudahan dalam mengontrol system kerja rumah pintar dapat dilakukan dengan mudah. Sehingga diketahui bahwa banyak keunggulan yang dapat diperoleh dengan penggunaan atau penerapan system Internet of Things tersebut.

\section{a. Mengontrol keadaan rumah setiap saat}

Meskipun pemilik rumah harus meninggalkan rumahnya selama berhari-hari, mereka tak perlu khawatir karena kemampuan IoT yang dapat memproteksi isi ruangan didalam rumah.

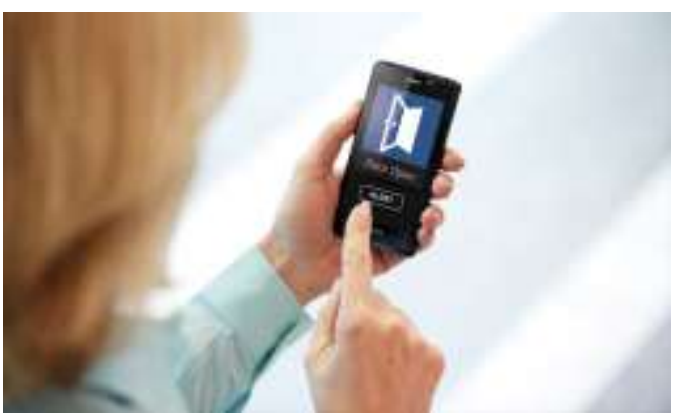

Gambar 5. Gadget sebagai remote control rumah pintar

Beberapa pengembang mengaplikasikan teknologi pada rumah pintar yang memungkinkan pemiliknya untuk membuka dan menutup tirai melalui komputer atau gadget. Untuk keamanan, juga dimungkinkan memantau rumah melalui kamera pengawas (CCTV) yang dipasang di beberapa sudut ruangan. Sehingga pemilik rumah bisa mengontrolnya setiap saat.

\section{b. Keamanan sangat terjamin}

Dengan adanya smart home dapat meminimalkan tingkat pencurian. Pada umumnya, ada beberapa smart home yang dibenamkan pintu berbasis teknologi. Bukan lagi mengandalkan kunci sebagai jalan pembuka lubang pintu, melainkan sudah menggunakan kartu, sidik jari, atau password. Artinya, hanya penghuni rumah yang dapat mengakses untuk masuk ke dalam rumah.

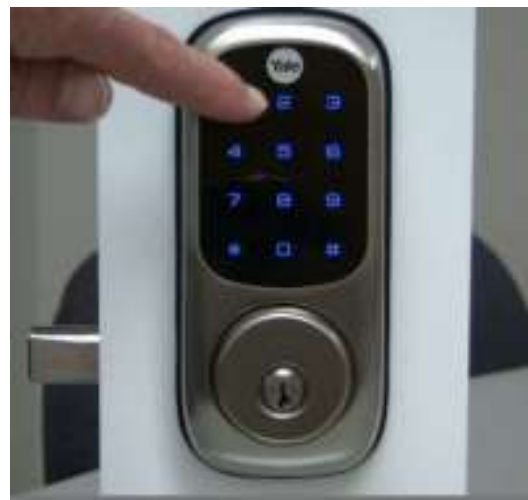

Gambar 6. Teknologi penguncian pintu rumah [7]

Di samping itu, pemilik rumah bisa melihat wajah tamu secara yang berkunjung ke rumah secara close up melalui tablet yang terkoneksi dengan kamera. Disamping itu, pemilik rumah juga dapat melakukan interaksi dengan tamu/pengunjung. Namun, jika ada tamu tak diundang sedang berdiri di depan rumah, pe,ilik rumah dapat langsung menghubungi kantor polisi lewat peranti yang terpasang di smart home.

\section{c. Kendali dalam satu perangkat}

Pada konsep smart home, segala pengaturan produk elektronik mulai dari televisi, DVD, sound system, hingga lampu akan dikendalikan dalam sebuah gadget. Pengguna hanya cukup mengontrolnya pada gadget sehingga tidak perlu khawatir dengan jumlah remote yang banyak.

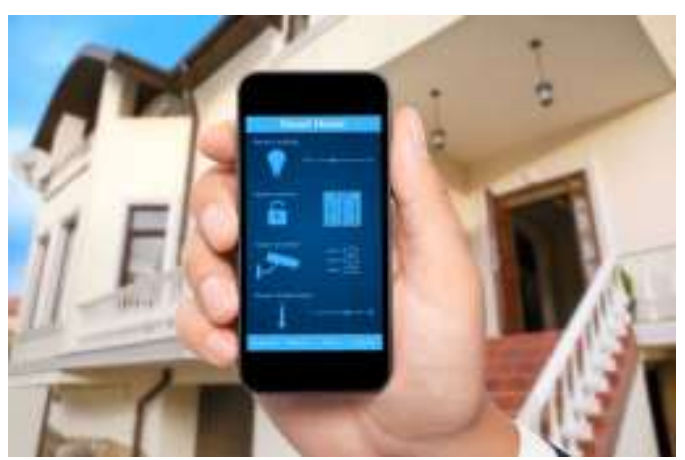

Gambar 7. Peran gadget sangat penting dalam mengontrol system kerja rumah pintar

\section{d. Alarm setiap agenda penting}

Konsep smart home ini juga dapat membantu pemilik rumah untuk mengingat setiap agenda yang telah direncanakan. Karena terhubung dengan gadget, sehingga mereka dapat mengaplikasikan agenda untuk ditampilkan di 
Jurnal Ilmiah Ilmu Komputer Vol. 6, No. 1, April 2020

Fakultas Ilmu Komputer

Universitas AL Asyariah Mandar

kaca atau disebut smart mirror. Disamping itu smart mirror juga berfungsi menampilkan animasi tampilan padu-padan pakaian untuk memilih baju secara virtual. Smart mirror sendiri terbuat dari layar LED ataupun touch screen.

\section{e. Ramah lingkungan dan energi}

Ternyata konsep rumah pintar ini juga menjunjung tinggi ecogreen atau ramah lingkungan. Demi mengusung efisiensi energi untuk kehidupan yang berkelanjutan, rumah pintar dibekali dengan sistem penampungan air hujan sebagai alternatif dari penyedotan air tanah. Bahkan hasilnya dapat diminum secara langsung berkat teknologi Reverse Osmosis system. Selain itu untuk kebutuhan listrik sehari-hari, rumah ini memanfaatkan tenaga surya. Hasilnya, penggunaan listrik PLN bisa dihemat 10 hingga 20 persen.

Fitur penting dari rumah pintar adalah konservasi sumber daya yang terbatas di bumi. Semakin banyak orang menjadi sadar akan kemampuan membuat rumah mereka benar-benar cerdas dan hijau dengan memanfaatkan pengendali rumah yang terintegrasi dengan semua subsistem rumah untuk meningkatkan penghematan dengan mengendalikan pencahayaan, penutup jendela, HVAC, irigasi dan dengan memantau penggunaannya.

Konsep rumah pintar dengan penggunaan teknologi Internet of Things (IoT) telah banyak diterapkan saat ini. Dimana pengendali rumah memiliki sistem pemantauan terpadu yang memiliki fitur untuk menghitung dan mencatat penggunaan semua perangkat yang terhubung, sehingga pemilik rumah tahu untuk mengatur kinerja perangkat sesuai kebutuhan. Sistem ini bahkan bisa diakses melalui internet dari manapun di dunia sehingga pemilik rumah bisa menyesuaikan pemakaian kapan saja dan dimana saja. Disamping itu, dengan teknologi Internet of Things (IoT) dapat menjamin keamanan dari bangunan rumah maupun penghuninya itu sendiri. Sehingga teknologi ini memang dapat mendukung terwujudnya rumah pintar yang menjadi rumah impian banyak masyarakat.

\section{KESIMPULAN}

Pada dasarnya, rumah pintar atau smart home adalah rumah yang menyediakan kenyamanan, keamanan, efisiensi energi bagi rumah setiap saat. Teknologi ini dapat bekerja saat orang ada di rumah maupun tidak ada di rumah. Internet yang dapat digunakan di semua perangkat membuat penggunanya bisa berinteraksi langsung dengan beberapa perangkat rumah tangga yang ada dirumah. Hal ini sejalan dengan tujuan IoT yang menghubungkan hampir semua perangkat untuk berinteraksi setiap harinya dengan manusia melalui koneksi internet.
(P) ISSN 2442-451X

(O) ISSN 2503-3832

Namun, tantangan terbesar yang bisa menjadi hambatan dalam mengkonfigurasi IoT adalah Sebagian besar biaya pengembangan IoT masih tergolong mahal dan dan sangat tergantung pada koneksi internet sehingga menuntut penggunanya untuk memiliki tingkat stabilitas internet yang tinggi.

\section{Daftar Pustaka}

[1] Hildayanti, A., Suriadi, N. A., \& Santosa, H. R. (2014). Analysis of housing areas with a sustainable community approach. Int. J. Sci. Eng. Res, 5, 15111517.

[2] Turner, John FC. (1972). Freedom to Build, Dweller Control of the Housing Process. New York : The Macmillan Company.

[3] Turner, John FC. (1976). Housing By People. London : Marion Boyars Publisher Ltd.

[4] Hildayanti, A., Wunas, S., \& La Tanrang, S. REVIEW PROCEDURES FOR BUILDING HOUSING AND SETTLEMENT WITH THE CONCEPT OF GREEN RIVER FLOWING RIVER PAMPANG AREA MAKASSAR CITY.

[5] Rapoport, Amos. (1969). House Form and Culture. Englewood Cliffs, N.J.:Prentice Hall

[6] Hildayanti, A., \& Machrizzandi, M. S. R. (2020). THE APPLICATION OF IOT (INTERNET OF THINGS) FOR SMART HOUSING ENVIRONMENTS AND INTEGRATED ECOSYSTEMS. Nature: National Academic Journal of Architecture, 7(1), 80-88.

[7] Ikhsanti, Dyah. (2015). Mau Investasi Smart Home? Kenali Dahulu Fitur-fiturnya. https://www.aturduit.com/articles/mau-investasismart-home-kenali-dahulu-fitur-fiturnya/ diakses pada 15 maret 2020.

[8] Serba Serbi, Technology / 18 September 2019. https://idcloudhost.com/mengenal-apa-itu-internet-ofthings-iot-defenisi-manfaat-tujuan-dan-cara-kerja/ diakses pada 15 maret 2020 